\title{
Linguo-Semantic Peculiarities of Kazakh Proper Names
}

\author{
Aigul Bizhkenova, Leilya Sabitova, Yevgeniya Bentya \\ ${ }^{1}$ Foreign Philology Department, Faculty of Philology, L.N. Gumilyov Eurasian National University, Kazakhstan
}

\begin{abstract}
The overall purpose of this article is to describe the peculiarities of Kazakh proper names. The conducted analysis resulted in several ways of formation - composition, word formation and borrowings. The article presents the origin of Kazakh proper names with translations and explanations of the meanings and their motivation origin.
\end{abstract}

Index terms - Kazakh proper name, anthroponym, composition, word-formation, suffixoid, prefixoid, motivation

\section{Introduction}

It is generally known that proper names are very important and are a specific category of words in any language. The origin and the history of proper names (nomina propria) is studied by different fields of science: philosophy, history, ethnography, geography, but the linguists are interested in proper names the most, they consider this category of words as an inalienable part of the language and speech. According to the theory of the proper names, this lexis has its own peculiarities. In particular, it is deficiency of significant element in the general semantics of the proper names; that means that the proper name does not have an independent conceptual meaning if it is not "embodied" (the term by Th. Hobbes) in the objective reality. What does it look like in a real life? Let's imagine that in some auditorium the following is said: "Let's welcome dear Akhmetkarim Sakenuly!"

The first conditions: the participants of the communication act know well the person who was presented. The response will be an adequate behavioural reaction of people.

The second conditions: the communicants do not know the announced person. As a result there will be no reaction unless the audience will pay attention to the person only because of curiosity. The name appeared to be meaningless for the participants of communication; it did not contain any information of its owner. That is can hardly be said that there was lack of information, it was the following: a person arrived, a man who probably has a certain social position, because he was introduced with his patronymic name. However this is not enough to associate a man with a certain personality, i.e. within the second conditions the name was "not embodied".

\section{Word-Composition Characteristics of Proper Names}

Genetically the proper names are the secondary naming unit in language, i.e. they are based on the common nouns. There is constant circulation of the proper names and the common nouns in the language. Their inter-transition is one of the natural sources of dynamics of the language vocabulary fund. Without going deep into the theoretical issues of the proper name (it is not the objective of this article) let's move to the consideration of Kazakh anthroponyms.
The process of giving names to a person is deeply social. The Kazakh people have their customs and traditions of this process. A research of several generations will show that the whole history and the development of Kazakh society are reflected in the proper names. The Kazakhs, survived anxious time and hunger, are God-fearing and law-abiding; they reacted to any changes in their life with the meaning of their children's names. So, most of the Kazakh names have a living etymon and motivation. Compound names are formed as a result of composition of nouns (or their stems) with verbs. Many proper names consist of names of animals and birds, phenomena, connected with religion, culture and Kazakh national traditions.

The proper names are mostly composed with affixation suffixoids and prefixoids. It is generally known that suffixoids and prefixoids are word-composing elements which when adding to a stem compose a new word. Their difference from suffixes is defined by the fact that in the dictionary suffixoids and prefixoids are verbal signs with an independent lexical meaning and are broadly used in the language. Some of them are bek (a man of an upper class), bai (rich), khan (governor), zhan (soul), ai (the moon), nur (light), gul (flower), bi (judge), sultan (sultan), tore (leader), shah (shah), zada (child), myrza (sir), bibi (woman), khanym (madam) and some others. Different prefixoids and suffixoids can be added to the same stem (which has a certain meaning) and form different proper names. For instance: form amir (lord) the following names are formed: Amirzhan, Amirbai, Amirbek, Amirkhan. This set of word-composition elements are generally used for formation of men's proper names. The examples of women's names are the following: form the stem (y)rym (bringing success and luck) - Rymgul, Rymzhan; form the stem nur - Ainur, Nurgul, Bibinur, Nurzada, etc. Besides the last element can be met as a stem and word-formation constituent in men's names, cf.: Nursultan, Nurtai, Nurbai, Nurbek, Nurzhan. The last twenty years the names with the stem nur is very popular, most probably the explanation to this fact is the name of the President of Kazakhstan - Nursultan.

Kazakh proper names are often formed by the composition of names: Seitzhappar, Abilmazhin, Mukhammetali, Saparmurat, Akhmetkarim, etc. Wordcomposition is also a fact of appearance of names, in this case the elements of a name are "talking": Aiturgan (new moon (literally: the moon is born), Aiturgan (will be new moon (literally: the moon will be born)), Aizharyk (bright moon), Aisulu (beautiful moon). The examples show that the folk admired the moon and followed the moon periods, deified the moon (according to Muslim laws it is sacred, different folk belief are connected with it) that is why $A i$ (the moon, crescent) 
is frequently used in the proper names as a stem and wordcomposition element.

Cattle breeding was men's business, therefore every family wanted a boy to be born. The word er (man) and $u l$ (son) became an attribute of many proper names, in that connection the girls were named with a desire to give birth to a boy: Ultuar (will give birth to a boy), Ulbolsyn (let it be son), Ulmeken (may be a son), Ulzhan (sonnie); the boys were named Erbol (be a man), Erzhan (man's soul), Erlik (courage), Ernar (man's power). In the names Ermek (companion), Erlan, Erkin (free) the element $e r$ - is a part of the stem morpheme and does not bear any independent meaning.

\section{Semantic-Motivating Signs of Praenomina}

As it was abovementioned Kazakh praenomina are motivated lexical units. In such units the inner form is quite obvious. Below we are considering a range of anthroponyms, where the principles of verb modality, etymological readability of nominal parts of speech, in particular, substantive and substantivized verbs are laid. They are directly connected with the meaning they comprise.

\section{A. Modality of the meaning of proper names}

According to BLS (The big linguistic guide), B.D. Starichenok, the modality is "functional-semantic category, which uncovers various types of relations of the content to objective reality or expresses the attitude of the speaker to the utterance" [5:315-316]. Therethrough pragmatic trend of proper names, marked with verb modality, refers to one of the peculiarities of their inner form. It is essential to pay attention to the rule of formation of imperative mood (buiryk rai) in Kazakh. It can be forms of all three persons and both in singular and in plural. This attribute allows marking out two types of imperative form used in proper names for expressing modal content. The verbs in imperative mood, formed from the second person, singular, are very common in the process of Kazakh name giving.

Examples:

Male names: Espol (be clever), Dosbol (be friend), Nurbol (be light), Nurlan (shine), Kobei (multiply), Aldan (cheer up), Amantyr (live healthy), Zharas (correspond), etc.

Female names: Zhaina (be bright), Gulzhaina (bloom like a flower), Zhalgas (continue), etc.

The imperative Kazakh verb forms from the third person, singular, compose the following words.

Examples:

Male names: Baityrsyn (let him live wealthy), Bektyrsyn (let him live like a ruler), Ongarsyn (let him have luck), Zharylkasyn (let him give abundance), etc.

Female names: Tyrsyn (let her live), Ylbolsyn (let it be a boy), Bolsyn (let it be), etc.

Such words as Baigabyl, Yeleukabyl, Aitkabyl, etc. also refer to this category. They are formed from the phrase "Kabyl bolsyn!" The word "kabyl" from Arab language means "to be accepted", "to be approved". The phrase "Kabyl bolsyn!" is pronounced after the wishes directed to the Lord, which means "Let it be accepted/approved (by the Lord)". The verb in imperative mood "bolsyn" in these names is contracted, nevertheless the meaning remains.

The next group of the names is presented by the verbs in presumable future tense (bolzhaldy keler shak), which in Kazakh language is used to denote an action supposed or possible to implement in the future. For instance, among male names - Yesentur (will be born healthy), Yerzheter (will become mature), Saktar (will save, will keep), Bekzhasar (will be strong), Nuskar (will guide/direct). Among female names: Kuntuar (the day will come), Ultuar (the boy will be born).

In several male names the modality is given by verbal form of so called recent past tense (zhedel otken shak) -

1) examples formed from the first person, plural: Sagyndyk - (we) missed; Kuandyk - (we) were glad; Suyundik - (we) admired, etc.;

2) examples formed from the third person, singular: Amangeldy - has come safe; Baigeldy - (s/he) has been born wealthy; Rysaldy - (s/he) inherited happiness, etc.

The names in the form of so called actually past tense (buryngy otken shak) also can be met. In such names the ending of the first person is contracted: Suragan form suraganmyn(byz) - asked; Tilegen from tilegenmin(biz) wished; Tolegen from tolegenmin(biz) - paid, etc. Also to this group the following names can be referred - Aldabergen, Tanirbergen, Kudaibergen, which, in fact, are complete sentences: Alla, Tanir, Kudai bergen(edi) - Allah (Heaven, Lord) gave. People, hoping for the mercy of Allah and safety of their children, gave names where the compulsory component was the name of Lord: Kudaibergen, Tanirbergen (literally: Lord gave).

\section{B. Meanings expressed by other ranks of words}

In Kazakh language there are also names in the form of infinitive (tuiyk etistik), which according to their semantic and grammatical peculiarities are as well determined like action names (kimyl esim), i.e. they could be converted. For instance, Tileu - to wish/a wish; Toleu - to pay/a pay; Aitleu - to request/ a request, etc.

There are participle verb form in the structure of anthroponyms, for example: Ayapbergen "given out of pity", Bakbergen "the one who gave happiness", Bekturgan "lived as a governor", Erturgan "the one who gave birth to a man", Otegen "the one who compensated", Dosbergen "the one who gave a friend", etc.

The names where the semantics "to live" (tur(u) is present are quite common: Turlybek, Turlykhan, Tursynbek, Turmagambet, etc. The names formed from adverbs and adjectives are also quite frequent: in Astana live a girl with the name Kaganat (satisfactory), Asyl (unselfish), Eleusys (imperceptible), Elemes (unnoticeable), Uzak (lasting), Zhanuzak (lasting soul), Kunuzak (lasting day).

In Kazakh families till the middle of the XX century was very high level of child mortality this fact generated lots of specific names. In the families where the new born babies died a lot people thought that there was some reason so children were named with simple and plain names: Elemes "unnoticeable", Eleusiz - "imperceptible", Ultarak "slipsole", etc. That was done to defend a child from malefic. 
Nevertheless the dominant grammatical rank of words laing in the structure of Kazakh anthroponyms are nouns. The selection of the structures is various and it hardly can be classified, and there is no such need. The main point here is to see the fundamental lingual-semantic motives and trends. When giving a name the Kazakh choose a name with appropriate or expected qualities of the new born. For instance: Balta - "axe", Temir - "iron", Arystan - "lion", Sheker "sugar", Alma - "apple". In the meanings the comparison is inplicitle present: be as sharp as an axe, as solid as iron, as brave as a lion, as sweet as sugar or apple.

The nation that livelong breed the cattle revered the horses (zhylky) and sheep (koi). These animals are imprinted in all idioms, proverbs and sayings of Kazakh language and of course in the proper names. The honour to these animals, which supplied the Kazakhs with food and domestic things and clothing, is given in such anthroponyms as Zhylkybai, Koishybai, Koishibek, Zhylkaidar, Koizhygara, Zhylkybek, etc. The pastures for the cattle are also imprinted: Zhailyaubai, Zhailyaubek.

Some of Kazakh names are borrowed from other languages, for instance:

The weather and nature are represented in name stock: Zhanbyrshy, Zhanbyrbai (rainy), Tanatar (dawn (the sun is rising)), Karzhau (snowing), Tumanbai (fog), Boranbai (snowstorm). Generally the closeness of the nature and men is clearly traced in the Kazakh proper names.

Flora and fauna, mainly steppe, are broadly presented in anthroponymics, for instance in women's names: Sandugash (nightingale), Karlygash (swallow), Kyzgaldak (tulip), Raushan (rose), Zhupar (wormwood), Akseleu (stipa), Kalampyr (carnation), Agashpai (tree), Orken (stalk), Kuralai (young dappled deer), Bota (young camel); in men's names: Burkit (golden eagle) and its derivatives - Burkitbai, Burkitbek, Arystan (lion), Arystanbek, Beibars (leopard), Tylkibai (fox), Kyskyrbai (wolf), Koshkarbai (sheep), Tekebai (goat), Otarbai (rich with sheep stock), Zhylkaidar (speeding horses), etc.

More rear are the words which are motivated by the texts of beloved in folk works of art. For instance woman's name Akbantik (white bow) is borrowed from the song of the similar title by one of the most popular Kazakh composer Shamshi Kaldayakov with the words by contemporary Kazakh poet Mykhtar Shakhanov: Balausa kyz edin bir kezde, shashyna ak bantik bailagan...

Each period imprints in Kazakh onomastics. So there are well known names: abbreviation Mels (Marx, Engels, Lenin, Stalin), contraction Marlen (Marx, Lenin). The range of names like Soviet, Oktyabr (October revolution 1917), Sovkhozbek from "sovkhoz" (soviet farm), Sailau - election, Maidan front (front line (military)), Vokzal (railway station), Poezbai - from "poezd" (train) and other names that obviously refer to the period of soviet Kazakhstan

Many Kazakh names are borrowing from other languages, for instance: Zhangali - "valiant like Ali", it has Arabic origin. The borrowings are not the topic of this article, however it is interesting to demonstrate the names which are very popular among Kazakh people.

TABLE.I Examples of Kazakh Proper Names

\begin{tabular}{|c|c|c|c|}
\hline № & Proper name & Origin & Meaning \\
\hline 1 & Aidyn & Turk. & "bright" \\
\hline 2 & Aisha & Arab. & "life" \\
\hline 3 & Akim & Hebrew & "approved by God" \\
\hline 4 & Ali & Arab. & "tall" \\
\hline 5 & Aman & Lat. & "loveworthy" \\
\hline 6 & Arthur & Celt. & "bear" \\
\hline 7 & Azamat & Arab. & "majesty" \\
\hline 8 & Aziz & Arab. & "dear" \\
\hline 9 & Dalmat & Lat. & $\begin{array}{l}\text { "a resident of Dalmatia ", "east } \\
\text { cost of the Adriatic sea" }\end{array}$ \\
\hline 10 & Danat & Greek & "presented, given" \\
\hline 11 & Dina & Arab. & "religion" \\
\hline 12 & Erik & Old Germanic & "rich, manly" \\
\hline 13 & Esen & Arab. & "Beautiful" \\
\hline 14 & Gabdulla & Arab. & "servant of God" \\
\hline 15 & Gani & Arab. & "rich" \\
\hline 16 & Hakim & Arab. & "a doctor, a wiseman" \\
\hline 17 & Kadyr & Arab. & "powerful, almighty" \\
\hline 18 & Kali & Greek & "splendid" \\
\hline 19 & Karim & Arab. & "generous" \\
\hline 20 & Kasym & Arab. & "beautiful" \\
\hline 21 & Leila & Arab. & "night" \\
\hline 22 & Maira & Greek & $\begin{array}{l}\text { The name of a village in } \\
\text { Palestine Magdala }\end{array}$ \\
\hline 23 & Maria & Hebrew & "beloved, desired (female)" \\
\hline 24 & Muhammed & Arab. & "praised" \\
\hline 25 & Muhitdin & Arab. & "animating the belief" \\
\hline 26 & Muhtar & Arab. & "choose" \\
\hline 27 & Myrad & Arab. & "a wish to seek (look for smth)" \\
\hline 28 & Nabi & Arab. & "a prophet" \\
\hline 29 & Omar & Arab. & "to live long" \\
\hline 30 & Rakhilya & Greek & "sheep" \\
\hline 31 & Ruslan & Arab. & from Turkic Arslan "lion" \\
\hline 32 & Sadyk & Arab. & "sincere" \\
\hline 33 & Salikha & Arab. & "devout" \\
\hline 34 & Salim & Arab. & "healthy" \\
\hline 35 & Sapar & Arab. & $\begin{array}{l}\text { One of the months of Muslim } \\
\text { calendar }\end{array}$ \\
\hline 35 & Seifulla & Arab. & "sword of God" \\
\hline 36 & Seit & Arab. & "sir" \\
\hline 37 & Sophia & Greek & "wisdom" \\
\hline 38 & Sultan & Arab. & "master" \\
\hline 38 & Timur & Turkic & "iron" \\
\hline 39 & Zhamal & Arab. & "Beauty" \\
\hline 40 & Zhamilya & Arab. & "friend (female)" \\
\hline
\end{tabular}




\section{Anthroponyms of the New Epoch}

Olzhas Badinuly while analyzing the present tendencies in Kazakh names of children of XXI century notices that the Kazakhs always were glad to the birth of a child and great responsibility of parents was in what name their child would get. The author grieves that among the original Kazakh names appears to be names with negative emotions of history and economics of other contries: Bin Laden, Dagdarys (crisis) [1]. The evidence of low culture is the names given after the characters of soup operas; parents forget that the name should be not only sonorous but also socio-culturally important. According to the newspaper "Vechernyaya Astana" among unusual and strange names in 2012 there are such names like Yakha, Zhebe, Taina, Khurnissa, Pernekyz, Shokhrukhkhan, Okilakhon, Lionella, Gartmut and Brilliant [2]. In Karaganda oblast a Kazakh family puzzled the society by naming their son Yolka (Christmas Tree), his full name is Yolka Rakhanovich Rakhanov. The boy was not lucky to be born an hour before New Year 2013.

After the Summit in 2012 the new Kazakh girls appeared named as Sa'mita, and in the same year after the Asian Olympic Games - little Aziadas.

Today there is a tendency of Kazakhs to use Kazakh stems in the naming process. According to the data of Statistics Agency of the Republic of Kazakhstan the most popular names of children born in 2012 are for boys: Erasyl, Nurislam, Alikhan, Nurasyl, Miras, Sanzhar, Arsen, Nursultan, Nurdaulet, Dias, Aldiyar, Arman, Amir, Islam; for girls: Kausar, Aiaru, Inzhu, Aruzhan, Ayaulym, Madina, Aizha, Diana, Aizere, Zhanerke, Sezim, Alina, Nurai, Amina, Inkar, Sabina, Ayazhan.

The leaders of 2012 are Erasyl - 2567 boys and Aiaru 3685 girls.

In the beginning of 2013 the most popular names remain Erasyl, Alikhan and Sanzhar. The fanciest names for girls Aizere, Aiaru and Inzhu [3].

The last analytical data was published by The Agency of Republic of Kazakhsta of statistics in the beginning of 2013. The most popular names became by September 2013 are 20 names. The dominant is female name - Aizere, male name Alikhan. Less popular turned out to be Ersultan and Ayana, they are on the $20^{\text {th }}$ line on the rating. Among Slavic manes Artyom and Sofiya. In the first ten among male names is Aisultan. Less popular become such names as Islam, Ali, Kirill, Maxim, and Roman. Also the rating of such names as Madiyar, Damir, Aldiyar, and Ersultan is decreasing.

\section{Conclusions}

In conclusion it is important to underline one more time the significance of the personal name. It is known from the ancient times that the name carries a magic power and can influence a character and model a fortune of a person. The observation shows that namesakes are alike in mentality, character, and even in physical appearance. What is more curious that people with the same names have very similar life situation. These observations of a certain names carriers will be presented in further works. And explanation of it can be found only in the magic of the names.

Therethrough, the name for a child should be chosen with great responsibility for the future fortune of a man. The great Goethe wrote: "The name of a man is not a cloak, dangling on the shoulders, which can be held and smoothed but a cloth like if skin, clinging dress, it cannot be erased or cut without hurting the man" [4: 280].

The name is important not only from cultural, historical and social point of view but and from the point of spiritual life. The Prophet Muhammad once said: "In the last hour of life you will be called by your name and by the name of your father. Therefore give the children good names" [1].

\section{References}

[1] Badiruly O. Esti esimder eskerilse eken// Astany Akshamy, №3 (2913), 10 January, 2013

[2] Kakiye v mode imena?// Vechernyaya Astana, №7 (2928), 17 January, 2013

[3] Vasilyeva N. Nazovi menya tikho po imeni//Ekspress K, №80 (17680), 7 May, 2013

[4] Solomnik A. Filisofiya znakovyh system i yazyk. Minsk: MET, 2002, 408p.

[5] Bolshoi Lingvistichekiy Slovar. - Rostov-na-Donu, 2008. - 81p. 